\title{
コークス乾留時における 主亀裂内輻射伝熱モデルの検討
}

\author{
(キーワード 輻射伝熱, 有限要素法, コークス, 乾留, 亀裂)
}

- 1994. 8. 4 受理一

東北大学*1 上田 有孝, 青木 秀之

上野 明則 $* 2$, 三浦 隆利

\section{1. 緒 言}

コークス炉において生成するコークス塊は，加熱壁 より生成する主亀裂（炉壁に垂直に炉中心まで進展す る横亀裂）の進展により形成され，その寸法は主亀裂 生成の間隔，進展状態により決定される。コークス層 内に生成する亀裂は，コークス品質である塊強度，形 状および寸法等を直接決定するばかりではなく、コー クス炉内の熱拉よび物質移動に大きく影響し乾留偏差 および乾留効率の低下を引き起こす事が報告されてい

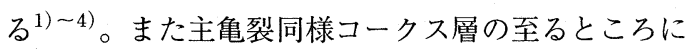
発生する微小亀裂および主亀裂表面から進展する亀裂 もコークス品質に大きく影響する現象であるが，その 生成原因は未だ十分解明されたわけではない。コーク ス中の微小な空隙内の輻射伝熱の寄与については, 多 孔質体内に打ける空隙内の輻射伝熱と同様にして有効 熱伝導率に含ませる事ができるが5 －7)，炉幅のほぼ 半分の寸法を有するコークス塊間の主亀裂内輻射伝熱 は微小亀裂と同様な方法で表す事は難しい。この観点 から当研究室では, 主亀裂内輻射伝熱が石炭・コーク ス層内温度場に与える影響を検討してきた ${ }^{899)}$ 。しか しながらコークス炉内温度場の実測が極めて困難であ り,コークス塊の変形や主亀裂の進展等が温度場に影 響を及ぼすため主亀裂内輻射伝熱モデルの予測精度に ついて検討することができなかった。そこで本研究で はコークス炉内をモデル化した小型加熱炬により，主 亀裂の進展したコークス塊を模擬した耐熱棟瓦の急速

*1 工学部生物化学工学科 仙台市青葉区荒巻字青葉

*2 現在, 三菱油化株式会社鹿島事業所

茨城県鹿島郡神栖町東和田17-1
端面加熱実験を行い，耐熱棟瓦内の温度分布を測定し 従来の石炭・コークス層亀裂内輻射伝熱モデル ${ }^{9)} に よ$ る解析結果と比較検討して, その妥当性を検討した。

\section{2. 実験方法}

Fig. 1 に室炉式コークス炉の模式図を示す。本実験 では実炬における石炭充填層の端面急速加熱時の主亀 裂により分断されるコークス塊を模擬している。Fig. 2 には試験体の寸法と温度測定部の詳細を示す。Fig.

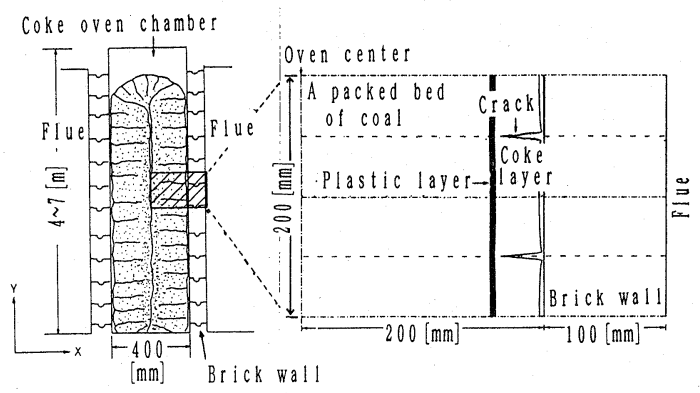

Fig.1 Schematic diagram of coke oven chamber

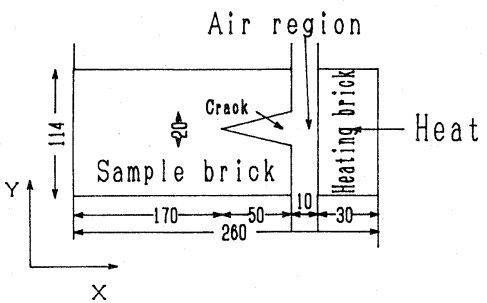

Fig.2 Schematic diagram of experimental apparatus 
1 中のコークス塊と加熱壁を Fig. 2 に示す様にモデ ル化した。試験体の材質には物性值が既知であり高温 においても変形・破壊を起こさない耐熱ブロック（イ ソライト社製 LBK-20）を使用した。試験体には長さ $220 \mathrm{~mm} \times$ 幅 $114 \mathrm{~mm} \times$ 厚さ $30 \mathrm{~mm}$ の耐熱棟瓦に長さ $50 \mathrm{~mm}$ の亀 裂を入れたものを用いた。各部の寸法は従来モデル ${ }^{9)}$ の解析で得られる乾留開始 4 時間後の塊寸法を参考に 決定した。ここで厚さ $30 \mathrm{~mm}$ の耐熱棟瓦（以下加熱ブ ロックと呼ぶ）は加熱壁を，幅 $10 \mathrm{~mm}$ の空隙は石炭・ コークス層の収縮により加熱壁との間に生じる空隙を， 試験体は亀裂を有する石炭・コークス層をそれぞれ模 擬している。Fig. 3 に加熱ブロックおよび試験体内の 温度測定の概略を示す。試験体内温度は，CA 熱電対 $(\phi 150 \mu \mathrm{m})$ により測定した。熱電対を試験体鉛直 方向に貫通させた $\phi 0.8 \mathrm{~mm}$ の穴に通して，熱電対の測 定点を深さ $15 \mathrm{~mm}$ (厚さの半分) の地点に設置し，アル ミナ耐火セメント（日本化学陶業社製 A-1-L）で固 定した。加熱ブロック内温度も同様にして測定した。 Fig. 4 には試験体と加熱ブロック内の熱電対設置位置 およびその座標（単位はmm）を示した。加熱ブロック 内では 4 点 (No. $1 \sim 4$ ), 試験体内では 12 点（No. 5 〜16）の合計16点で温度測定を行った。Fig. 5 に実験 炬の全体図を示す。長さ $800 \mathrm{~mm} \times$ 幅 $730 \mathrm{~mm} \times$ 高さ $500 \mathrm{~mm}$ の容器の中央に幅 $400 \mathrm{~mm} \times$ 高さ $145 \mathrm{~mm} \times$ 厚さ $20 \mathrm{~mm}$ の加熱 板を設置し，その前面に厚さ $30 \mathrm{~mm}$ の加熱ブロックを置 いた。温度分布を測定する試験体を加熱ブロック前面 の中央に置き，試験体各面の断熱条件を満足させるた めに，試験体の周囲を耐熱ブロックで囲み，更にその 周囲を断熱材により囲った。また，試験体と加熱ブ ロック間の空隙については，試験体周囲の耐熱ブロッ クと加熱壁間の空隙に断熱材を充填し，この断熱材に よって，試験体と加熱ブロック間の空隙を囲み，周囲 と隔離することで，この空隙内での対流伝熱の影響が 最小となるように配慮した。実験は予め加熱板前面に 置かれた加熱ブロックの温度が定常な温度分布になる

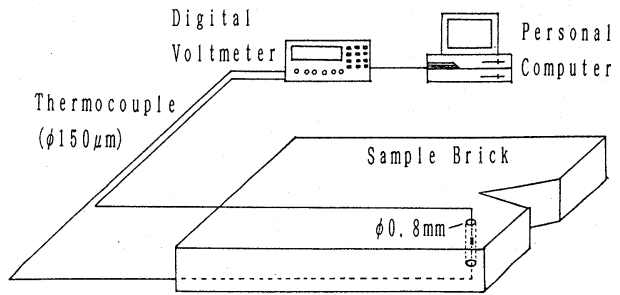

Fig.3 Schematic diagram of temperature measuring
までヒーターにより加熱した後（加熱開始 3 時間後）, 試験体を所定の位置に設置して急速加熱し, 試験体お了 よび加熱ブロック内の温度を測定した。

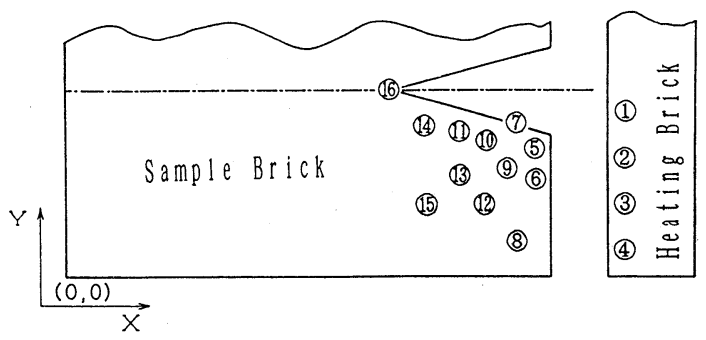

\begin{tabular}{|r|r|r|r|r|r|r|r|r|}
\hline No & 1 & 2 & 3 & 4 & 5 & 6 & 7 & 8 \\
\hline$X$ & 233 & 233 & 233 & 233 & 215 & 215 & 210 & 210 \\
\hline$Y$ & 52 & 37 & 22 & 7 & 49 & 32 & 49 & 10 \\
\hline
\end{tabular}

\begin{tabular}{|r|r|r|r|r|r|r|r|}
\hline 9 & 10 & 11 & 12 & 13 & 14 & 15 & 16 \\
\hline 205 & 200 & 190 & 200 & 190 & 180 & 180 & 170 \\
\hline 39 & 43 & 45 & 25 & 35 & 47 & 25 & 37 \\
\hline
\end{tabular}

Fig.4 Temperature measuring position in sample brick

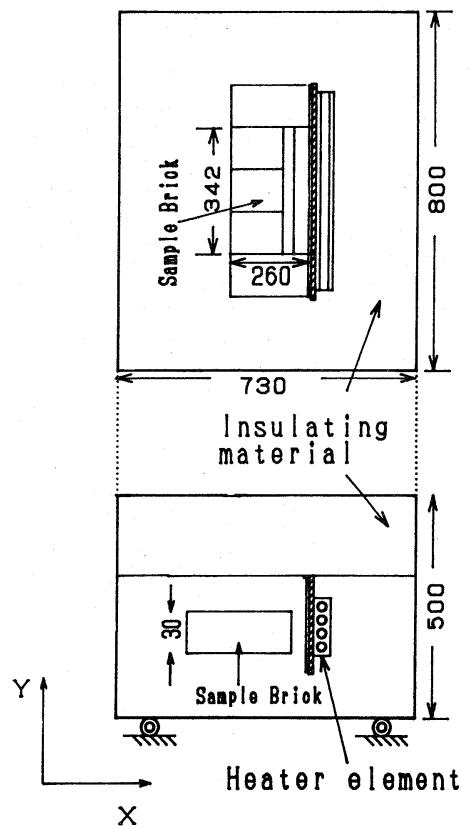

Fig.5 Schematic diagram of test furnance 


\section{3. 解析モデル}

モデル化にあたり，以下の仮定をおく。

（1）試験体および加熱ブロック内の温度分布は 2 次元 で表す事が出来る。

（2）試験体の各面は加熱ブロック側を除き断熱である。

（3）試験体と加熱ブロック間の空気層を通しての伝熱 は伝導および輻射伝熱が支配的であり，対流伝熱は 無視出来る。

以上の仮定により試験体，空気層および加熱ブロッ クのエネルギー収支式は式(1)で表される。

$\rho_{\mathrm{i}} \mathrm{C}_{\mathrm{pi}} \frac{\partial \theta}{\partial \mathrm{t}}=\operatorname{div}\left(\lambda_{\mathrm{i}} \operatorname{grad} \theta\right)+\mathrm{q}_{\mathrm{r}}$

$\mathrm{i}=$ brick $:$ Sample brick region

$\mathrm{i}=$ air : Air region

$\mathrm{i}=$ brick : Heated brick region

温度場の解析はエネルギー収支式(1)を Gelerkin 法に より有限要素法に定式化することにより行った。式中 の輻射熱流束 $\mathrm{q}_{\mathrm{r}}$ は文献 ${ }^{10)}$ に従って各要素間の熱流束 を求めた。試験体の亀裂面、加熱ブロックおよび加熱 ブロックに面する試験体面における任意の要素面 $\mathrm{i}$ か ら放射される正味の輻射エネルギー $\mathrm{q}_{\mathrm{ri}}$ は(2)式で表さ れる。

$$
\mathrm{q}_{\mathrm{ri}}=\left\{\varepsilon_{\mathrm{i}} /\left(1-\varepsilon_{\mathrm{i}}\right)\right\} \quad\left(\mathrm{E}_{\mathrm{bi}}-\mathrm{J}_{\mathrm{i}}\right)
$$

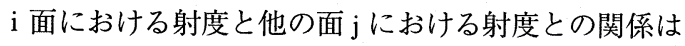
(3)式で表され，この式を全ての面に関して組み立て $\mathrm{N}_{\mathrm{b}} \times \mathrm{N}_{\mathrm{b}} \quad\left(\mathrm{N}_{\mathrm{b}}\right.$ : Number of radiation boundary) の 連立一次方程式を解けば各要素面の射度を求めること が出来る。

$$
\mathrm{J}_{\mathrm{i}}-\left(1-\varepsilon_{1}\right) \sum_{\mathrm{j}=1}^{\mathrm{Nb}} \mathrm{F}_{\mathrm{ij}} \mathrm{J}_{\mathrm{j}}=\varepsilon_{\mathrm{i}} \mathrm{E}_{\mathrm{bi}}
$$

なお式中の輻射形態係数 $\mathrm{F}_{\mathrm{ij}}$ は各輻射面間の幾何学的 な位置関係より求めた ${ }^{11)}$ 。本解析で用いた耐熱棟瓦
の熱物性値および各初期条件を Table 1 に示す。こ こで耐熱棟瓦の輻射率 (AGEMA 社製サーモビジョン870およびサーマルイ メージコンピュータ TIC-8000を使用。）を用いて実測 した值（ $\varepsilon=0.66 ）$ を用いた。また計算は時間刻みを $1 \mathrm{sec}$ として行った。Fig. 6 には解析に使用した計算 グリッドを示す。本解析では，亀裂で区切られる $1 / 2$ 領域を解析対象とした。グリッドは従来モデル ${ }^{9)}$ と分 割数の等しい1372要素, 750節点であり, 亀裂部分及 び加熱ブロックと試験体間の空隙は, 実際のコークス 塊内熱応力解析における輻射伝熱モデルの妥当性を検 討する意味からその場合と同様に，対称面上に存在す る微小要素が変形した空間とした。Fig. 7 に解析領域 の境界条件を示す。眓に示す通り解析領域のヒーター 側の境界 1 は加熱ブロックの試験体側表面より $3 \mathrm{~mm} の$ 加熱ブロック内に設けた。そして境界1より右側の領 域の要素の節点には境界 1 と同様な温度を与えた。 Fig. 8 に加熱ブロック内の測定点（No. 1〜4）にお

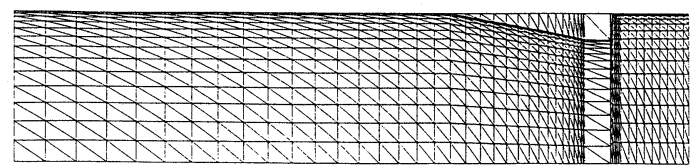

Fig.6 Geometrical configuration of grid elements

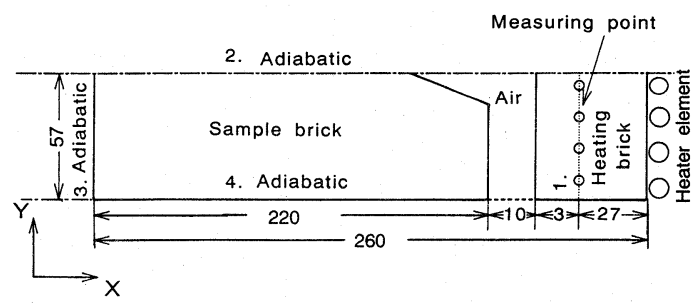

Fig.7 Illustration of temperature boundary condition

Table 1 Thermophysical property and initial condition of brick and air

\begin{tabular}{l|c}
\hline $\begin{array}{c}\text { Effective thermal conductivity } \\
\text { of brick } \lambda_{\text {effb }}[\mathrm{W} / \mathrm{m} \cdot \mathrm{K}]\end{array}$ & $\lambda_{\text {effb }}=0.35 \times(1+0.99 \theta)$ \\
\hline $\begin{array}{c}\text { Heat capacity of brick } \\
C_{\mathrm{pb}}[\mathrm{kJ} / \mathrm{kg} \cdot \mathrm{K}]\end{array}$ & $\begin{array}{c}9.23 \sim 10.89 \\
\text { (Spline interpolation) }\end{array}$ \\
\hline $\begin{array}{c}\text { Density of brick } \\
\rho_{\mathrm{b}}\left[\mathrm{kg} / \mathrm{m}^{3}\right]\end{array}$ & 45 \\
\hline Emissivity of brick $[-]$ & 0.66 (Measured) \\
\hline $\begin{array}{c}\text { Initial temperature of } \\
\text { sample brick }[\mathrm{K}]\end{array}$ & 297 \\
\hline Initial temperature of air $[\mathrm{K}]$ & \\
\hline
\end{tabular}




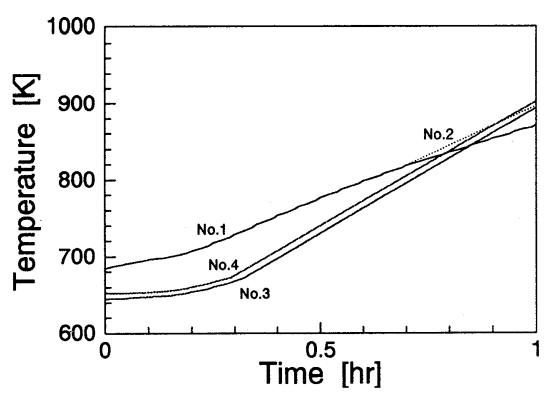

Fig.8 Temperature distribution in heating brick (boundary condition)

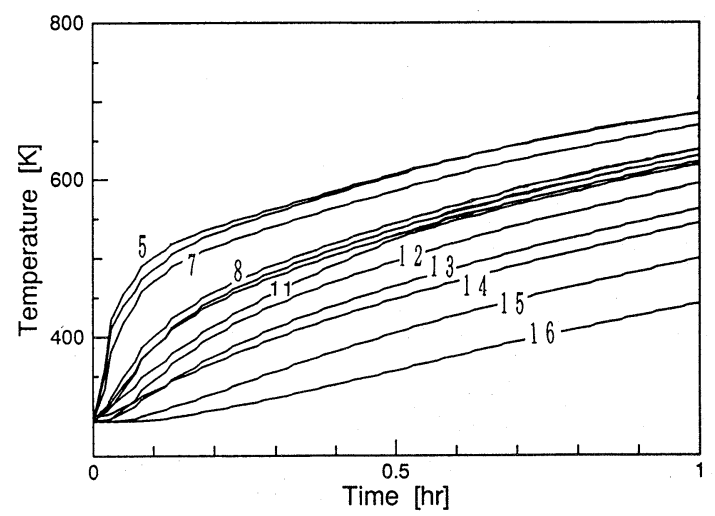

Fig.9 Variation of temperature in sample brick

ける温度の経時変化を示す。境界 1 の温度の実測値を 時間については最小自乗法により 1 次の関数で近似し, 場所についてはNo. 1〜 4 の値を最小自乗法により 2 次の関数で近似して, 境界 1 の境界条件として与えた。 また，Fig. 7 中の境界 2，3，4 面は断熱とした。加 熱ブロックと試験体間の空隙の空気層の初期温度は予 熱により加熱ブロックの温度と同等とみなせることか ら, 空気層の初期温度は加熱ブロック内温度と等しい 温度 $(927 \mathrm{~K})$ とした。

\section{4. 結果と考察}

Fig. 9 にFig. 4 中の試験体内の各測定点（No. 5 16）における温度の経時変化を示す。加熱開始直後は 各点ともそれぞれ異なる昇温速度で加熱されているが, 加熱開始 0.5 時間以降では各点ともほぼ同じ一定の昇 温速度で加熱されている。また加熱ブロックから遠い 測定点ほど昇温が緩やかであり，加熱方向に温度勾配 が生じている。

Fig.10,11には加熱面近傍の測定点No. 5，6におけ る温度経時変化の実験值と解析値の比較を示す。No. $5 ， 6$ 共に加熱面近傍の測定点であるため，ほぼ同様

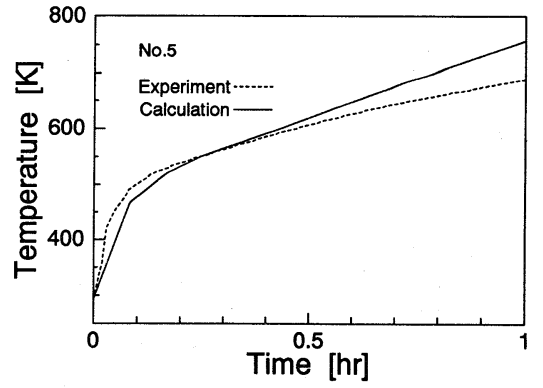

Fig.10 Comparison of measured and calculated temperature at measuring point of No. 5

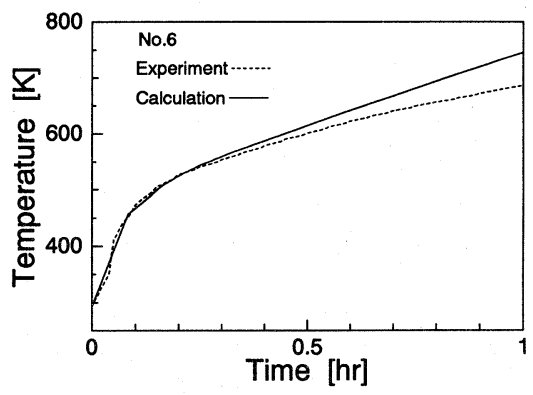

Fig.11 Comparison of measured and calculated temperature at measuring point of No. 6

の傾向を示している。加熱後期には解析值が害験値を 上まっているものの加熱初期では解析結果は実験結果 と良好に一致している。解析值に比べて実験值が低い 值をとる原因としては, 実験において加熱壁から遠ざ かる程大きくなる周囲への放熱の影響や加熱ブロック と試験体の間の空隙での要素分割が粗いこと等が挙げ られる。Fig.12,13には試験体内の加熱面から $20 \mathrm{~mm}$ 離 れた測定点No.10,12における温度経時変化の実験値と 解析值の比較を示す。ここでも加熱初期では解析結果 は実験結果と良好に一致しているが，加熱後期にはや はり実験值が解析值よりやや低い值を示している。ま た，加熱後期における実験値と解析値の差はNNo.10よ りもNo.12の方が大きくなっている。これはNo.12の方 が輻射を受ける面から離れているため輻射伝熱の影響 が小さく，伝導による周囲への放熱の影響が大きくな るためと考えられる。Fig.14には亀裂先端に設置した 測定点No.16における温度経時変化の実験值と解析值 の比較を示す。ここでは周囲への放熱の影響が小さく， 解析結果は実験結果と良好に一致している。

次に加熱面から等距離にある二つの測定点を比較す る。Fig.15(a)，(b)には加熱面に近い測定点No. 5， 6 の実験と解析における温度経時変化の比較をそれぞれ 


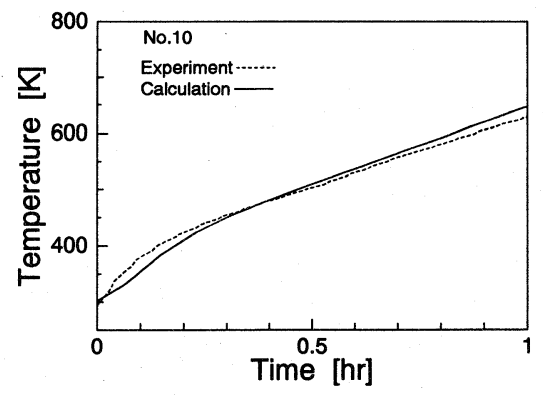

Fig.12 Comparison of measured and calculated temperature at measuring point of No.10

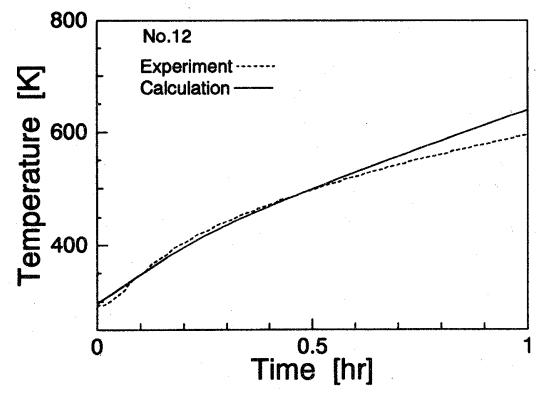

Fig.13 Comparison of measured and calculated temperature at measuring point of No.12

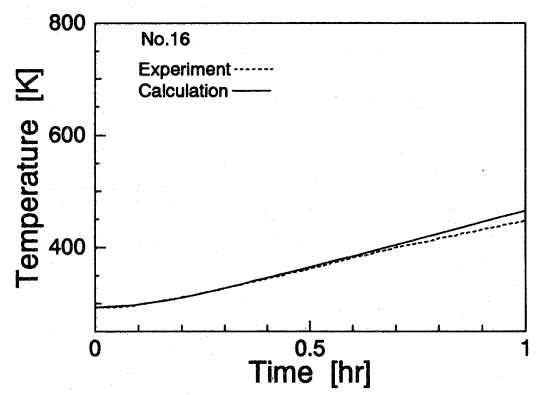

Fig.14 Comparison of measured and calculated temperature at measuring point of No.16

示す。この二つの図を見ると, 解析結果は実験結果に おけるNo. 5 ，№. 6 間の温度差を良好に再現している ことがわかる。Fig.16(a)，(b)には加熱面から $20 \mathrm{~mm}$ 離れ た測定点No.10，12の実験と解析における温度経時変 化の比較をそれぞれ示す。ここでも解析結果と実験結 果は良好に対応している。Fig.15(a)，(b)，16(a)，(b)を 見ると, No. 5，6間の温度差（Fig.15(a)，(b)）に比 ベてNo.10,12の間の温度差（Fig.16(a)，(b)）はやや大 きくなっていることがわかる。これはNo.10,12では No.12が輻射を受ける面から離れているため伝導によ

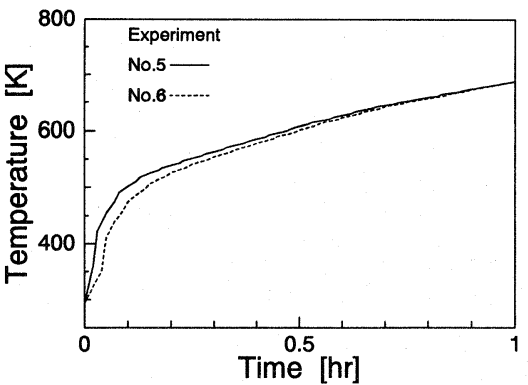

Fig.15(a) Measured temperature at measuring point of No. 5 and No. 6

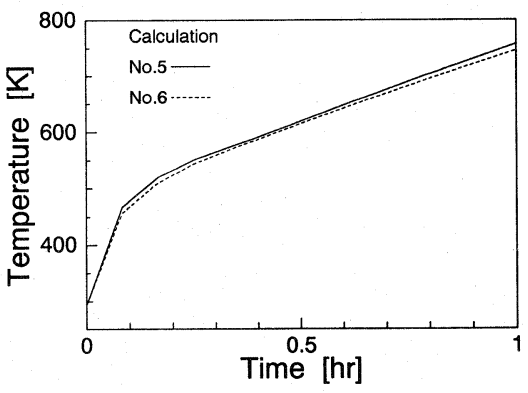

Fig.15 (b) Calculated temperature at measuring point of No. 5 and No. 6

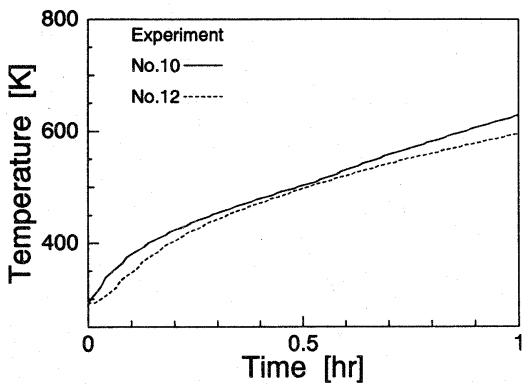

Fig. 16(a) Measured temperature at measuring point of No. 10 and No.12

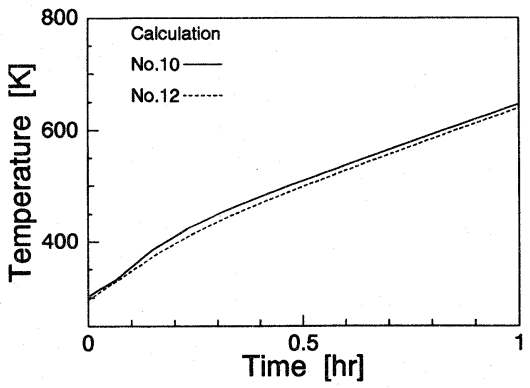

Fig.16 (b) Calculated temperature at measuring point of No. 10 and No. 12 


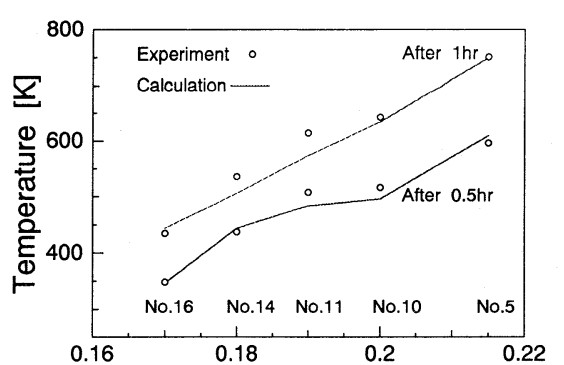

Horizontal position in sample brick [m]

Fig.17 Temperature distribution in sample brick (near crack surface region)

る周囲への放熱の影響により両測定点間の温度差が大 きくなるのに対して, No. 5，6の場合では両測定点 とも輻射を受ける面に近く両測定点間の温度差があま り生じないためと考えられる。つまり輻射を受ける面 から離れている測定点では伝導による周囲への放熱の 影響が大きくなるが, 解析ではこの放熱の影響は考慮 していないため, 実験值と解析値に開きが生じると考 えられる。逆に輻射を受ける面（加熱面および亀裂 辺）に近い測定点では, 特に加熱初期において, 解析 值と実験值は良好に一致していた。

Fig.17に試験体内における亀裂辺に沿った $\mathrm{x}$ 方向温 度分布を示す。亀裂辺沿いの X 方向の温度勾配は実 験結果, 解析結果とも同様の傾向となっており, 解析 結果は実験結果を良好に再現している。以上より本モ デルによる輻射熱流束の推算值は妥当であると考えら れる。

\section{5. 結 言}

耐熱煉瓦を試験体とした端面急速加熱実験および亀 裂辺内輻射伝熱を考慮した解析を行い, 両者を比較検 討した。その結果, 加熱面近傍および亀裂辺周辺の加 熱初期における温度分布は実験・解析共に同様の傾向 となり, 当研究室で従来から使用してきた輻射伝熱モ デルによる輻射熱流束の見積りは妥当であることが示 された。今後の検討課題としては, 亀裂辺周辺の加熱 ブロックに大きな温度勾配のある場合や, 実炬と同様 にガス輻射の影響が顕著な場合における解析モデルの 妥当性の検討が望まれる。

\section{[記 号]}

$\begin{array}{lr}\mathrm{C}_{\mathrm{p}}: \text { Heat capacity } & {[\mathrm{kJ} / \mathrm{kg} \cdot \mathrm{K}]} \\ \mathrm{E}_{\mathrm{bi}}: \text { Emissive power of blackbody } & {\left[\mathrm{W} / \mathrm{m}^{2}\right]} \\ \mathrm{F}_{\mathrm{ij}}: \text { Radiation shape factor } & {[-]} \\ \mathrm{J}_{\mathrm{i}}: \text { Radiosity } & {\left[\mathrm{W} / \mathrm{m}^{2}\right]} \\ \mathrm{N}_{\mathrm{b}}: \text { Number of radiation boundary } & {[-]} \\ \mathrm{q}_{\mathrm{r}}: \text { Radiative heat flux } & {\left[\mathrm{W} / \mathrm{m}^{2}\right]} \\ \mathrm{t} \quad: \text { Time } & {[\mathrm{s}]} \\ \mathrm{X} \quad: \text { Horizontal distance } & {[\mathrm{mm}]} \\ \mathrm{Y} \quad: \text { Vertical distance } & {[\mathrm{mm}]} \\ \langle\text { Greek Symbols }> & {[-]} \\ \varepsilon_{\mathrm{i}}: \text { Emissivity } & {[\mathrm{K}]} \\ \theta \quad: \text { Temperature } & {[\mathrm{W} / \mathrm{m} \cdot \mathrm{K}]} \\ \lambda \quad: \text { Thermal conductivity } & {\left[\mathrm{kg} / \mathrm{m}^{3}\right]} \\ \rho \quad: \text { Density } & \\ <\text { Subscripts }> & \\ \text { air }: \text { Air } & \\ \mathrm{b} \quad: \text { Brick } & \\ \mathrm{i} \quad: \text { i'th species } & \\ \text { j } \quad: \text { j'th species } & \end{array}$

文 献

1) Merrick, D., Fuel, 62, 547 (1983)

2）三浦 潔, 井上恵三，高谷幸司，西岡邦彦，鉄と 鋼, 77, 1243 (1991)

3) Rohde, W., Habermehl, D. and Kolitz, V., Ironmaking Conference Proceedings, 47, 135 (1988)

4）西岡邦彦, 井上恵三, 三浦 潔, 吉田周平, 佐知 孝文，材料とプロセス， 4，145(1991)

5）西岡邦彦, 吉田周平, 播木道春, 鉄と鋼, 70, 358 (1984)

6) Kasperczyk, J. and Simons, W., Gluckauf-Forschungshefte, 32, 23 (1971)

7）山田健彦, 大木 厳, 奥井信之, 田村洋一, 高島啓 行，越後格之，燃協誌，56，36（1977）

8）墚井 潤，三浦隆利，大谷茂盛，鉄と鋼，73，629 (1987)

9) 佐藤洋史, 有馬 孝, 三浦隆利, 化学工学論文集, 17, 1146 (1991)

10) Holman, J. P., 伝熱工学 (下) (丸善), 333 (1982)

11）国井大蔵，熱的単位操作 (上) (丸善)，74 (1976) 


\title{
Estimation of Radiative Heat Transfer Model in the Lump Coke with Crack During Coal Carbonization
}

\author{
Aritaka UEDA ${ }^{* 1}$, Hideyuki AOKI ${ }^{* 1}$, Akinori UENO*2 \\ and Takatoshi MIURA*1 \\ $\left(\begin{array}{ll}* 1 \text { Department of Biochemistry and Engineering, Tohoku University } \\ * 2 \text { Kashima Works, Mitubishi Petrochemical Co., Ltd. }\end{array}\right)$
}

SYNOPSIS :- Lump coke size is determined mainly by the growth of macro-crack from the wall side to center in the coke oven chamber, where the carbonization period and the coke quality are determined by the heat and mass transfer. Although the radiative heat transfer of porous media within the micro-crack can be included in an effective thermal conductivity, the effect of radiative heat transfer within the macro-crack on temperature and stress distribution in coal/coke layer have to be investigated analytically using the finite element method.

In this study, a rapid heating experiment of the brick with a macro-crack is carried out in the laboratory-scale coke oven to measure the temperature distribution in the brick. The heat transfer model including the radiative heat transfer within the macro-crack is estimated by comparing the calculated result with the experimental one in order to confirm the accuracy of temperature field in our ordinary thermal stress analysis model. As a result, the calculated history of temperature distribution in the sample brick is in good agreement with experiments especially near the macro-crack surface.

\section{Key Words}

Radiative heat transfer, FEM, Coke, Carbonization, Crack 